\title{
Appraisal of the Emerging Risks under Global Climate Change on Quercus Robur Species in Romania
}

\author{
Mihai MOLDOVAN $^{1 *}$, Ioan OROIAN ${ }^{1}$, Tania MIHAIESCU ${ }^{1}$ \\ ${ }^{1}$ Department of Environment and Plant Protection, Faculty of Agriculture, University of Agricultural \\ Sciences and Veterinary Medicine Cluj-Napoca, Romania \\ * corresponding author: mihai.mpc@gmail.com \\ Bulletin USAMV series Agriculture 72(1)/2015 \\ Print ISSN 1843-5246; Electronic ISSN 1843-5386 \\ DOI 10.15835/buasvmcn-agr: 11164
}

\begin{abstract}
The Quercus robur is an important and predominant species in Romania representing around $17.7 \%$ of the total forest surface. The present research aims to study the influence of the climate changes on the development of several fungal pathogens and in particular the research of the powdery mildew on the oak species in different climate conditions. The influence of various climatic conditions and the soil properties on the development of pathogens at the Quercus species, was studied using data collected over a period of 2 years. The meteorological data used were: the average temperature values, the thermal regime of extreme values, the monthly precipitation regime and the ecometrical parameters values of the thermal and hydric regime; and the soil analysis were: humidity, soil reaction, humus content, total nitrogen, base saturation and exchange capacity. The results were that in topsoil, soil reaction varies from 4.59 to $5.65 \mathrm{pH}$ units and total humus content varies from very low (0.882\%) to good (4.246\%). Total nitrogen content in the studied plot range from $0.05 \%$ to $0.22 \%$, the average being in the low class $(0.14 \%)$. In conclusion the disease is favoured by climatic factors and infections occur when the average daily temperature is above $15^{\circ} \mathrm{C}$ and air humidity is about $80 \%$ during summer, followed by short rainy periods, the powdery mildew appears predominantly on the upper leafs under the appearance of white spots which grow gradually.
\end{abstract}

Keywords: climate change, disease, pathogen, powdery mildew, Quercus robur.

\section{INTRODUCTION}

Until the beginning of the XIX century our country was known as an "oak country", later on the composition of forests was continually modified, as a result of anthropic and climate changes over the years. This forest composition, dominated by oak, with over $47 \%$ changed radically mainly because of uncontrolled deforestation of the oak in the plains, and in our time the oak percentage reached $17.7 \%$ of the forest surface, although even this small percentage of oak struggles with diseases and various pests or from various improper technical solutions (Giurgiu, 2004).
What is known as the "drying" or the "decline of forests" is a complex phenomenon due to the evolution of environment conditions from the forests. Various factors - climatic, pedological, biologic and anthropic have influence on the forest ecosystems, and permanently modify the ecological balance. The forest decline manifested itself in two ways, one through deforestation, which was not followed by regeneration of the forest; and the other one was forest degradation (Marcu, 1966).

A healthy forest has a special importance for society, because the forest's surface in $26.7 \%$ of 
the countries surface and over $30 \%$ of the rural area, and the positive influences of the forests are larger than the surface that they cover (Giurgiu, 2004).

In the forests of our country we can find a large number of diseases and pests which can cause significant damage to the trees. Following the attacks of pests and diseases the trees slow down their growth, and their vitality is significantly diminished, and the development of phythopathogens is favoured, and frequently fighting these is a long and hard process, which can be impossible at times.

\section{MATERIALS AND METHODS}

Before setting the objectives of the research a series of real problems faced by the forest practice were identified, as the producing of forest material needed for forestation. The observations, experiences and observations were made during 2 years, 2012 and 2013.

The influence of various climatic conditions on the development of pathogens at the Quercus species, was studied using data collected over a period of 2 years (the average temperature values, the thermal regime of extreme values, the monthly precipitation regime and the ecometrical parameters values of the thermal and hydric regime). Specific soil conditions were also analysed.

To establish the way that the powdery mildew fungus's development is favoured by climatic factors, periodical observations were made on the development of the disease and the climatic conditions.

The soil sampling was made considering the Order of the Minister of Agriculture, Food and
Forestry (MAFF) no. 223/2002 and STAS 7184/184. Soil samples were collected from O.S Dej tree nursery at the depth of $0-5 \mathrm{~cm}, 5-20 \mathrm{~cm}$ and 20-55 cm. 0.5 to $1 \mathrm{~kg}$ of soil was collected for each sample. The samples were placed in clear polythene bags, which were labelled clearly. All soil samples were air-dried at ambient temperature and were sieved to remove stones and plant debris, and mixed thoroughly to obtain a representative sample.

Standard laboratory procedures were used for soil sample analysis: humidity (SR ISO 11465:1998), soil reaction (pH) (SR 718413:2001, using the InoLab Multi 720 multimeter, WTW, Germany), humus content (wet oxidation, method Walkley-Black modified by Gogoasa, SR ISO 14235:2000), total nitrogen (SR ISO 11261:2000, using Kjeldahl Digestion and Distillation Units VELP Scientifica, Italy), the soil percentage base saturation, the content of exchangeable bases, total cation exchange capacity (SR EN ISO 11260:2012) and particle size analysis (STAS 7184/10-79). All reagents were of analytical-reagent grade type (Merck) and all solutions were prepared using ultrapure water with a specific resistance of 18.2 $\mathrm{M} \Omega \mathrm{cm}^{-1}$. Analyses were made in triplicate and the mean values were reported. Weather data was provided by O.S Dej. Statistical analysis on the data was carried out using IBM SPSS Statistics ver.22.0.0 software.

\section{RESULTS AND DISCUSSIONS}

In topsoil, soil reaction varies from 4.59 to $5.65 \mathrm{pH}$ units and total humus content varies from very low $(0.882 \%)$ to good $(4.246 \%)$. Total nitrogen content in the studied plot range from $0.05 \%$ to $0.22 \%$, the average being in the low class $(0.14 \%)$ (Table 1$)$.

Tab. 1. Results concerning the main soil properties in the studied area

\begin{tabular}{|c|c|c|c|c|c|c|c|c|c|c|c|c|}
\hline$\dot{0}$ & $\frac{\Xi}{2}$ & 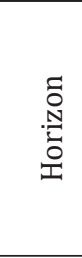 & 己 & 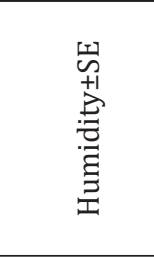 & 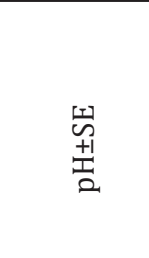 & 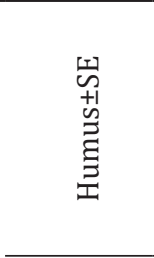 & 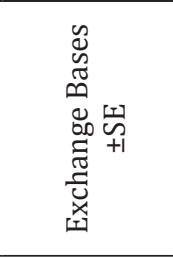 & 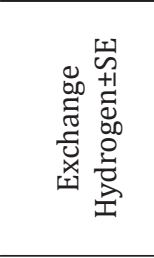 & 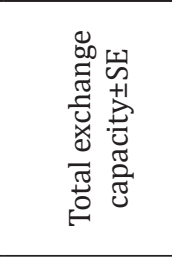 & 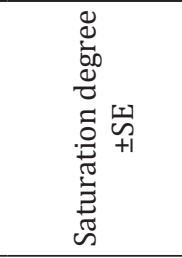 & 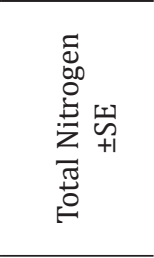 & שِّ \\
\hline & & A.B.C & $\mathrm{cm}$ & $\%$ & & $\%$ & $\mathrm{me} \%$ & $\mathrm{me} \%$ & $\mathrm{me} \%$ & $\mathrm{me} \%$ & $\mathrm{~g} \%$ & \\
\hline 1 & $\begin{array}{l}\overline{0} \\
\text { ஜ }\end{array}$ & Ao & $0-5$ & $2.51 \pm 0.02$ & $4.85 \pm 0.03$ & $4.25 \pm 0.2$ & $10.95 \pm 0.10$ & $7.56 \pm 0.04$ & $18.51 \pm 0.06$ & $59.15 \pm 0.23$ & $0.22 \pm 0.02$ & $1-n$ \\
\hline 2 & . & Elw & $5-20$ & $1.91 \pm 0.02$ & $4.59 \pm 0.32$ & $2.87 \pm 0.10$ & $5.85 \pm 0.06$ & $8.11 \pm 0.12$ & $13.96 \pm 0.81$ & $41.88 \pm 0.78$ & $0.15 \pm 0.03$ & l \\
\hline 3 & 芯 & Btw & $20-55$ & $3.45 \pm 1.01$ & $5.65 \pm 1.64$ & $0.88 \pm 0.26$ & $12.05 \pm 3.95$ & $5.50 \pm 1.60$ & 17.555 .58 & $68.66 \pm 21.63$ & $0.04 \pm 0.02$ & $\mathrm{l}-\mathrm{a}$ \\
\hline
\end{tabular}




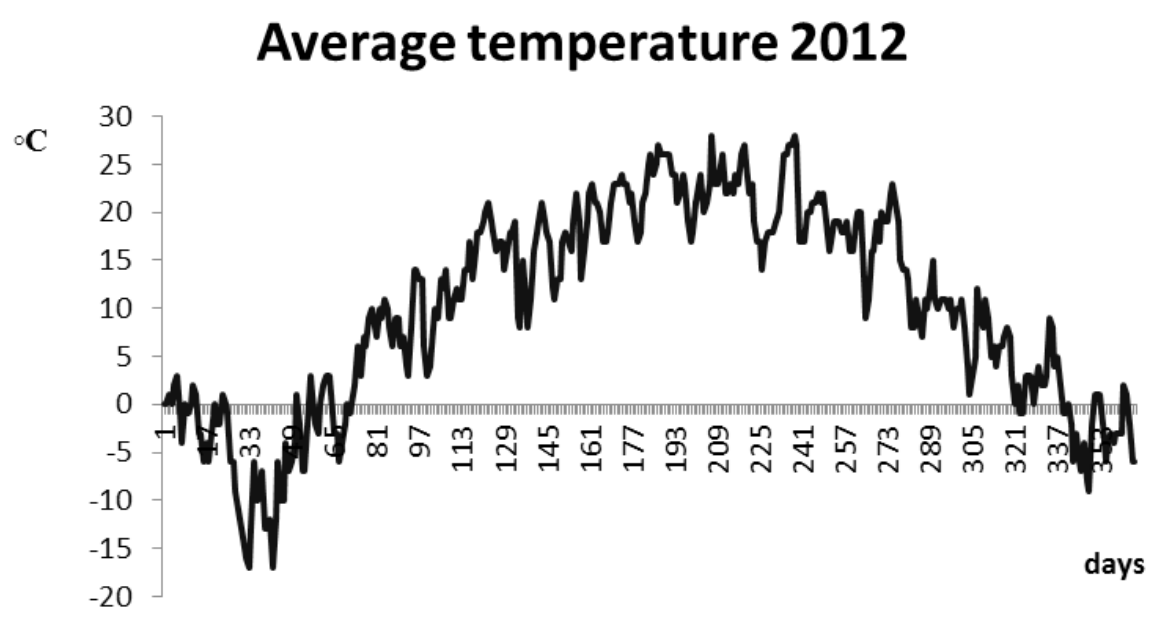

Fig 1. Average daily temperatures recorded in 2012

\section{Average temperature 2013}

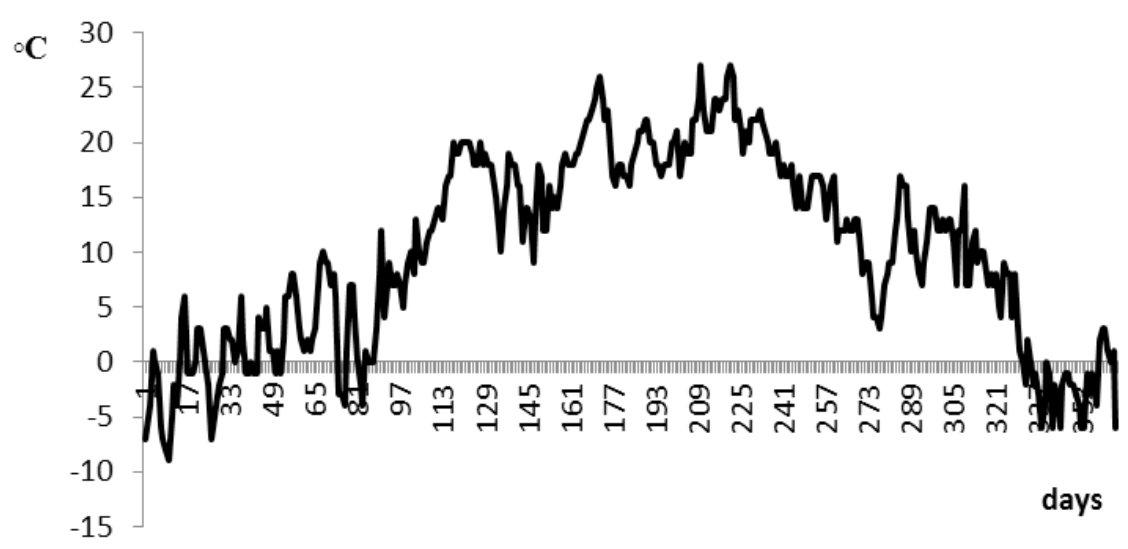

Fig 2. Average daily temperatures recorded in 2013

\section{Precipitation sum 2012}

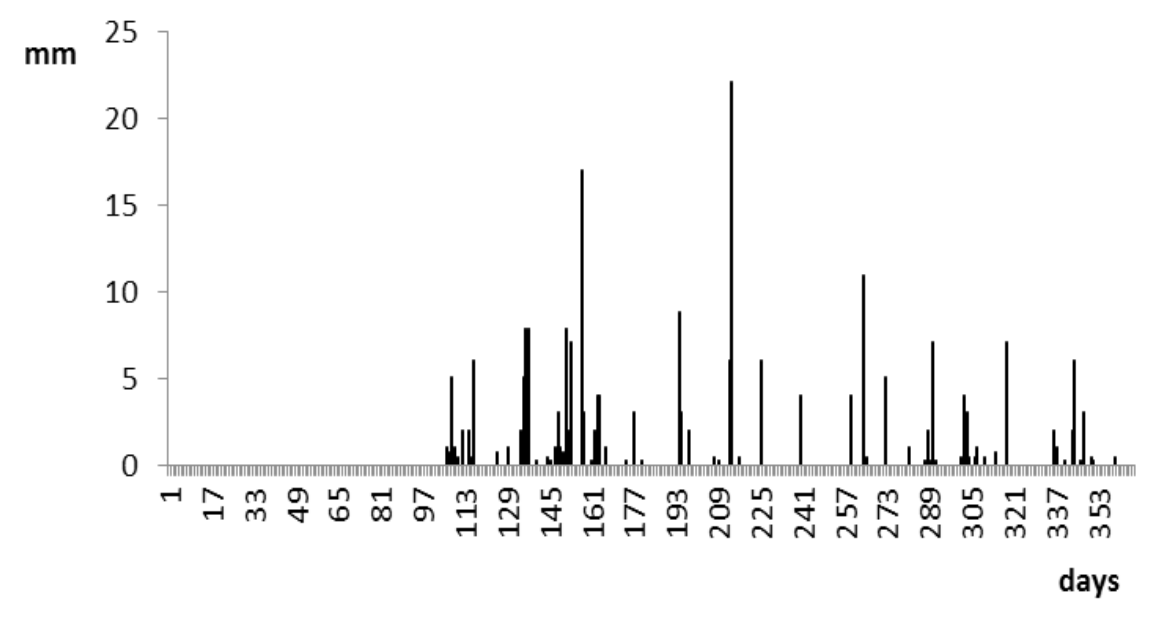

Fig 3. Average daily precipitation sum recorded in 2012 


\section{Precipitation sum 2013}

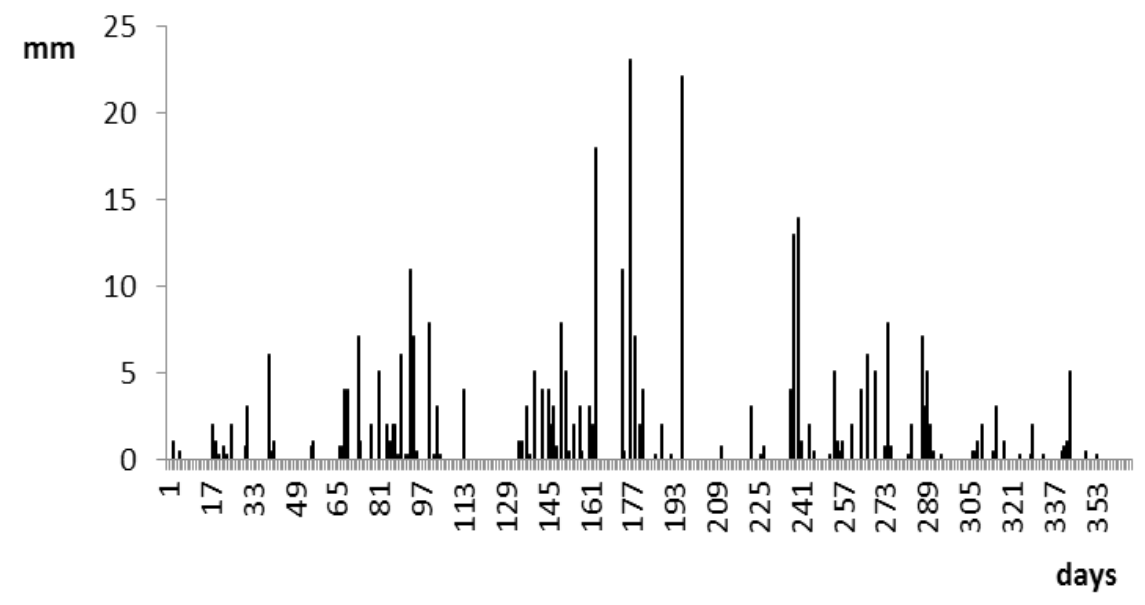

Fig 4. Average daily precipitation sum recorded in 2013

Humidity 2012

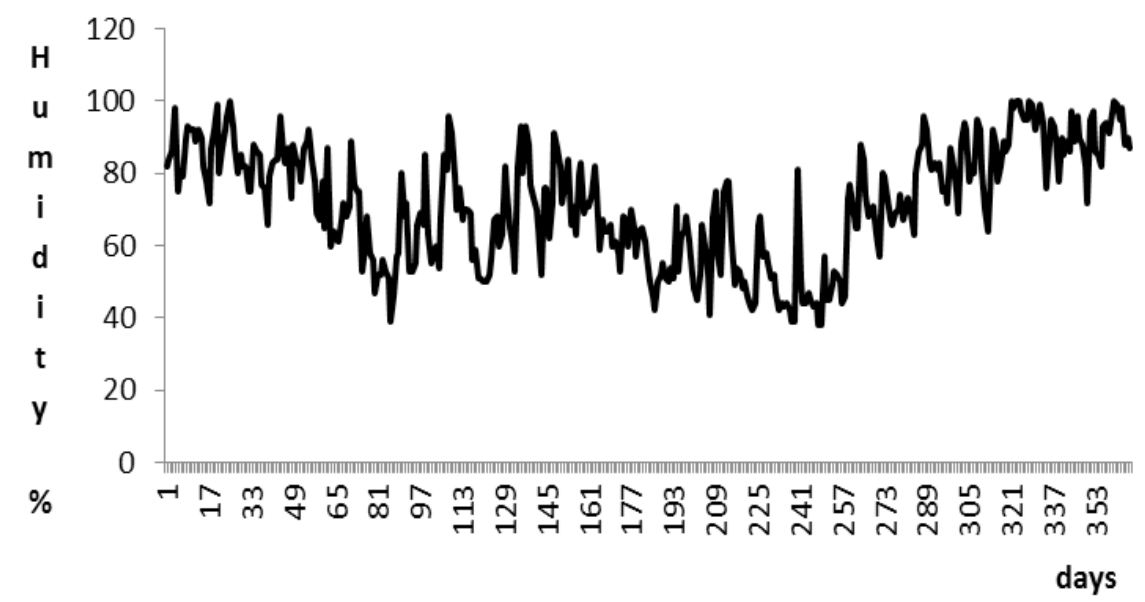

Fig 5. Humidity 2012

Humidity 2013

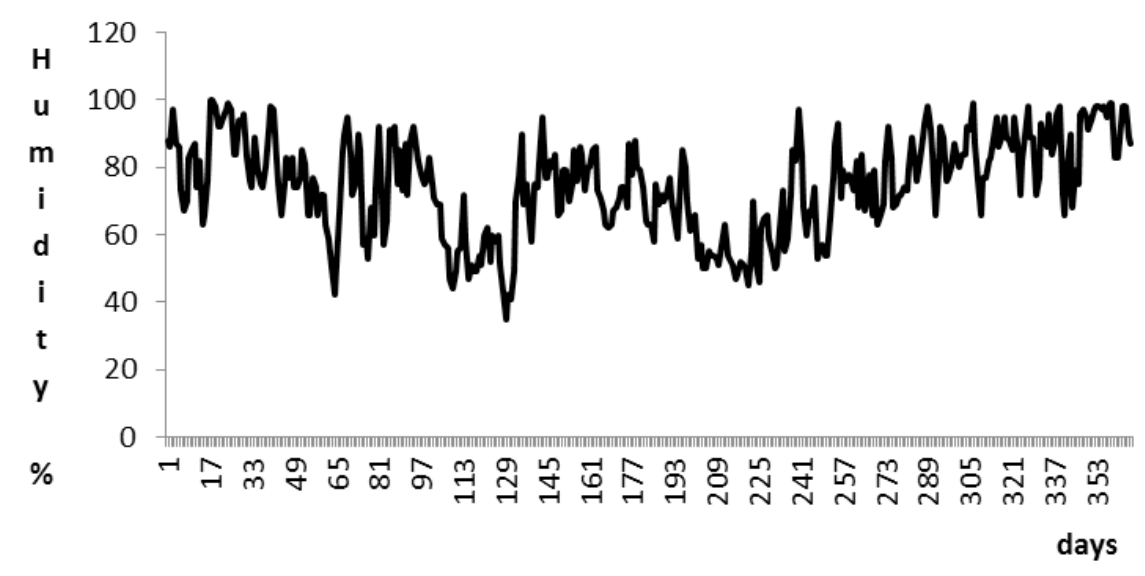

Fig 5. Humidity 2013 


\section{CONCLUSION}

The disease is favoured by climatic factors and infections occur when the average daily temperature is above $15^{\circ} \mathrm{C}$ and air humidity is about $80 \%$ during summer, followed by short rainy periods, the powdery mildew appears predominantly on the upper leafs under the appearance of white spots which grow gradually.

From Fig 1. results that in the year 2012 there were 162 days with temperatures over $15^{\circ} \mathrm{C}$ and from Fig 5. it results that there were 148 days with humidity over $80 \%$.

From Fig 2. results that in the year 2013 there were 196 days with temperatures over $15^{\circ} \mathrm{C}$ and from Fig 6. it results that there were 206 days with humidity over $80 \%$.

In conclusion from the study of the temperature and humidity graphics for the 2 years, it results that the year 2012 had a medium degree of occurrence for the powdery mildew disease and the year 2013 had a high degree of occurrence for the powdery mildew disease.

The occurrence of the disease is favoured by climatic factors, the infections occur when the daily medium temperature stabilizes at values over $15^{\circ} \mathrm{C}$ and the atmospheric humidity at the leaf level is about $80 \%$. During the warm season the infestations are produced after short rainy periods. The mycelium appears on the upper part of the leaves ad white spots which are progressively enlarged.

The annual loss of seedlings in nurseries due to this disease is in between $10-15 \%$ and in some conditions can reach $20 \%$. In addition to the loss of seedlings there are significant growth reductions which damage the young trees and an increased vulnerability to frost.
Acknowledgements. This paper was published under the frame of European Social Fund, Human Resources Development Operational Programme 2007-2013, project no. POSDRU/159/1.5/S/132765.

\section{REFERENCES}

1. Badea 0 (2006). Starea de sănătate a pădurilor din România în perioada anilor 1990-2005, evaluată prin sistemul de monitoring forestier. Revista Pădurilor 1:813.

2. Giurgiu V (2004). Gestionarea durabilă a pădurilor României. Silvologie III B. Ed. Academiei Române, București.

3. Marcu G (1966). Studiul cauzelor și al metodelor de prevenire și combatere a uscării stejarului. Centrul de docum. tehn. pt. ec. forest., București.

4. ${ }^{* * *}$ SR EN ISO 11260:2012, Soil quality - Determination of effective cation exchange capacity and base saturation level using barium chloride solution (ISO 11260:1994+Cor 1:1996).

5. ${ }^{* * *}$ STAS $7184 / 12-88$, Soils. Determination of cation exchange properties.

6. ***SR ISO 11261:2000, Soil quality. Determination of total nitrogen. Modified Kjeldahl method.

7. ***SR ISO 11465:1998, Soil quality. Determination of dry matter and water content on a mass basis - gravimetric method.

8. ***SR ISO 14235:2000, Soil quality. Determination of organic carbon by sulfochromic oxidation.

9. ***STAS $7184 / 10-79$, Soils. Determination of grain composition

10. ***SR 7184-13:2001, Soils. Determination of $\mathrm{pH}$ in water and saline suspensions (mass/volume) and in saturated paste.

11. ***STAS 7184/1-84, Soils. Sampling for pedologycal and agrochemical investigations. 